\title{
Lateral Periodontal Cyst: a Case Report and Literature Review
}

\author{
Luis Felipe das Chagas e Silva de Carvalho' ${ }^{1}$, Celina Faig Lima ${ }^{2}$, Luiz Antonio Guimarães Cabral', \\ Adriana Aigotti Haberbeck Brandão ${ }^{3}$, Janete Dias Almeida ${ }^{3}$
}

${ }^{1}$ Postgraduation Program in Oral Biopathology, São José dos Campos Dental School, São Paulo State University - UNESP, São José dos Campos, São Paulo, Brazil and Postgraduation Program in Nanosciences and Advanced Materials, Federal University of ABC, Santo André, São Paulo, Brazil

${ }^{2}$ Postgraduation Program in Oral Biopathology, São José dos Campos Dental School, São Paulo State University - UNESP, São José dos Campos, São Paulo, Brasil

${ }^{3}$ Department of Biosciences and Oral Diagnosis, São José dos Campos Dental School, São Paulo State University - UNESP, São José dos Campos, São Paulo, Brazil

\author{
Corresponding Author: \\ Janete Dias Almeida \\ Faculdade de Odontologia de São José dos Campos - UNESP \\ Departamento de Biociências e Diagnóstico Bucal \\ Av. Francisco José Longo, 777 São Dimas, 12245-000, São José dos Campos, São Paulo \\ Brazil \\ Fax: 055211239479010 \\ E-mail: janete@,fosjc.unesp.br
}

\begin{abstract}
Background: The lateral periodontal cyst is considered a developmental odontogenic cyst with unusual occurrence. In most cases it is preliminary diagnosed as a radiographic finding, presenting as well circumscribed or as a round or teardrop-shaped radiolucent area. Due to its location it can easily be misdiagnosed as a lesion of endodontic origin. Final diagnosis should be based on histopatological examination. The purpose of this paper is to report a classic case of lateral periodontal cyst located in the anterior region of mandible and to review the relevant literature which describes the clinical, radiological and histopathological features of lateral periodontal cysts.

Methods: A 50 years female patient complained of an asymptomatic gingival swelling in the region between the left mandibular lateral incisor and canine. Radiographic examination revealed a well circumscribed radiolucency with approximately $0.5 \mathrm{~cm}$ diameter with a radiopaque margin between the roots of the left mandibular lateral incisor and canine. The adjacent teeth had vital pulp.

Results: A total enucleation of the lesion was performed, and intraoperative examination showed a single lesion with no communication between the cyst's cavity and the oral environment. Histological examination revealed that the lesion was "lateral periodontal cyst of developmental origin". There was no recurrence or complications for 24 months follow-up.

Conclusions: The lateral periodontal cyst can be considered in the differential diagnosis when a radioloucent lesion appears adjacent to the roots of vital teeth. The treatment of choice is surgical removal and subsequent histological evaluation to confirm the diagnosis. Relapses are infrequent.
\end{abstract}

Keywords: periodontal cyst, apical; radicular cyst; odontogenic cysts; jaw cysts.

Accepted for publication: 21 October 2010

To cite this article:

de Carvalho LF, Lima CF, Cabral LA, Brandão AA, Almeida JD. Lateral Periodontal Cyst: a Case Report and Literature Review.

J Oral Maxillofac Res 2010 (Oct-Dec);1(4):e5

URL: http://www.ejomr.org/JOMR/archives/2010/4/e5/v1n4e5ht.pdf

doi: $\underline{10.5037 / \text { jomr.2010.1405 }}$ 


\section{INTRODUCTION}

Odontogenic cysts are classifed by the World Health Organization as infammatory and developmental according to their epithelial lining. Lateral periodontal cysts (LPC) have been regarded as an independent condition [1-4].

LPCs are defined as nonkeratinized and noninflammatory developmental cysts located adjacent or lateral to the root of a vital tooth. This cyst's most frequent location is at the level of mandibular premolars but it has been reported occurring in the other areas [5].

LPC is one of the cysts of lower incidence among developmental odontogenic cysts. Since pain or other clinical symptoms have seldom been reported, the lesion is often discovered on routine radiographic examination. Radiographs of the lateral periodontal cyst show a well-circumscribed round or ovoid radiolucent area, usually with a sclerotic margin. Most of them are less than $1 \mathrm{~cm}$ in diameter [5-8].

Histologically, the lateral periodontal cyst is a distinct type of developmental cyst characterized by a thin, nonkeratinized epithelium usually 1 to 5 cell layers thick, which resembles the reduced enamel epithelium. The epithelial lining exhibits focal thickenings or plaques, in which clear glycogen-containing epithelial cells have often been found. The connective tissue subjacent to the epithelium exhibits a zone of hyalinization [9].

It presents unique characteristics and there is an important differential diagnosis with lesions of endodontic and periodontal origin, and other cysts from the same group [5-8]. The pathogenesis of LPC, the gingival cyst of the adult, the botryoid odontogenic cyst and the glandular odontogenic cyst may be correlated [1]. Some authors, based on the clinical and morphological similarities, reinforce that the gingival cyst of the adult and LPC present a common histogenesis, and these lesions may have the same extra-osseous and intra-osseous characteristics, respectively [10].

This paper reports a classic case of LPC which is located in the anterior region of mandible, and also presents a brief literature review of the clinical, radiological and histopathological features of LPC.

\section{CASE DESCRIPTION AND RESULTS}

A 50 year old black female patient was referred to São Paulo State University - UNESP, São José dos Campos Dental School, Department of Biosciences and Oral Diagnosis, São José dos Campos, São Paulo, Brazil, complaining of mandibular left lateral incisor mobility. The patient reported that she had used the stick to tooth in this region, shortly before the change was observed, approximately six months ago.

Clinical examination revealed mild horizontal mobility of the tooth \#32. The palpation of vestibular surface of the alveolar process in the region of teeth \#32 and \#33 was asymptomatic. Vitality test demonstrated vital pulp of teeth \#32 and \#33.

Periapical radiograph of the site was taken. Radiographic examination revealed a well-circumscribed, unilocular, radiolucent area with approximately $0.5 \mathrm{~cm}$ in diameter adjacent to the roots of the left mandibular lateral incisor and canine (Figure 1).

On the basis of these findings, a clinical diagnosis of lateral periodontal cyst was made. Local anaesthesia was used and full-thickness mucoperiosteal flap was elevated. The cyst capsule was detached from the adjacent bone. A total enucleation of the lesion was realized using a surgical curette (Figure 2).

After enucleation, the cyst was histologically examined (Figure 3A). Histological sections showed a single cavity lesion lined by epithelium of variable thickness, sometimes displaying one or two layers of cuboid cells and sometimes showing areas that formed thick clusters of cells more voluminous in the midst of which several PAS positive clear cells were observed. The capsule consisted of fibrous tissue with several bleeding areas and absence of inflammation (Figure $3 \mathrm{~B}, \mathrm{C}$ and D). The histological findings supported the diagnosis of lateral periodontal cyst of developmental origin.

Follow-up of the case, twenty four months after operation, showed uneventful healing and spontaneous regeneration of bone in periapical radiography.

\section{DISCUSSION}

LPC is considered as developmental odontogenic cyst with unusual occurrence that may be associated with vital teeth. LPC represents approximately $0.8 \%$ to $2 \%$ of all odontogenic cysts $[1,9]$. Literature review shows that the LPC is more prevalent in adults in the 5 th -7 th

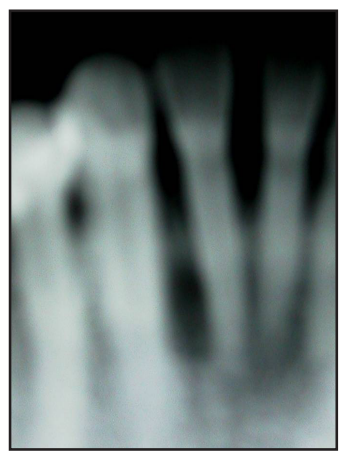

Figure 1. Periapical radiograph showing circumscribed radiolucent area located between two vital teeth \#32 and \#33 
decades, with mean age of 52 years, without preference for race or sex. The most frequently reported location of LPC is the mandibular premolar area, followed by the anterior region of maxilla (Table 1) $[\underline{5}, \underline{6}, \underline{8}, \underline{11-20}]$. In most cases the LPC does not present distinctive clinical symptoms; the associated teeth are vital, unless secondarily infected. Hence, the PLC is often discovered on routine radiographic examination.

The pathogenesis of LPC may be related to the three etiopathological hypotheses: reduced enamel epithelium [9], remnants of dental lamina [11] and cellular remnants of Malassez [1]. The first hypothesis is that the cyst is lined by nonkeratinized epithelium reminiscent of the reduced enamel epithelium which is supported by PCNA immunohistochemical expression. The second theory is related to dental lamina remnants,

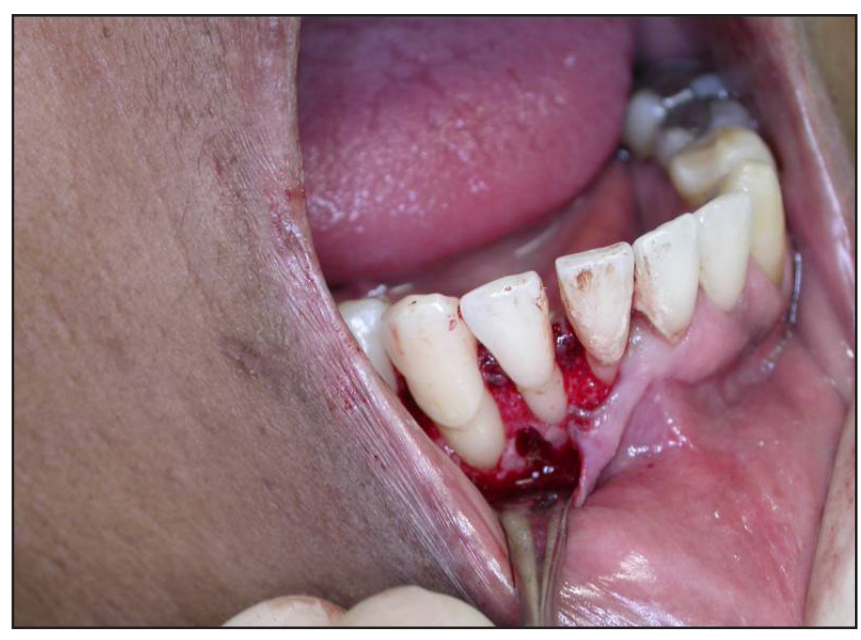

Figure 2. Photograph showing bone cavity after enucleation of the cystic lesion.
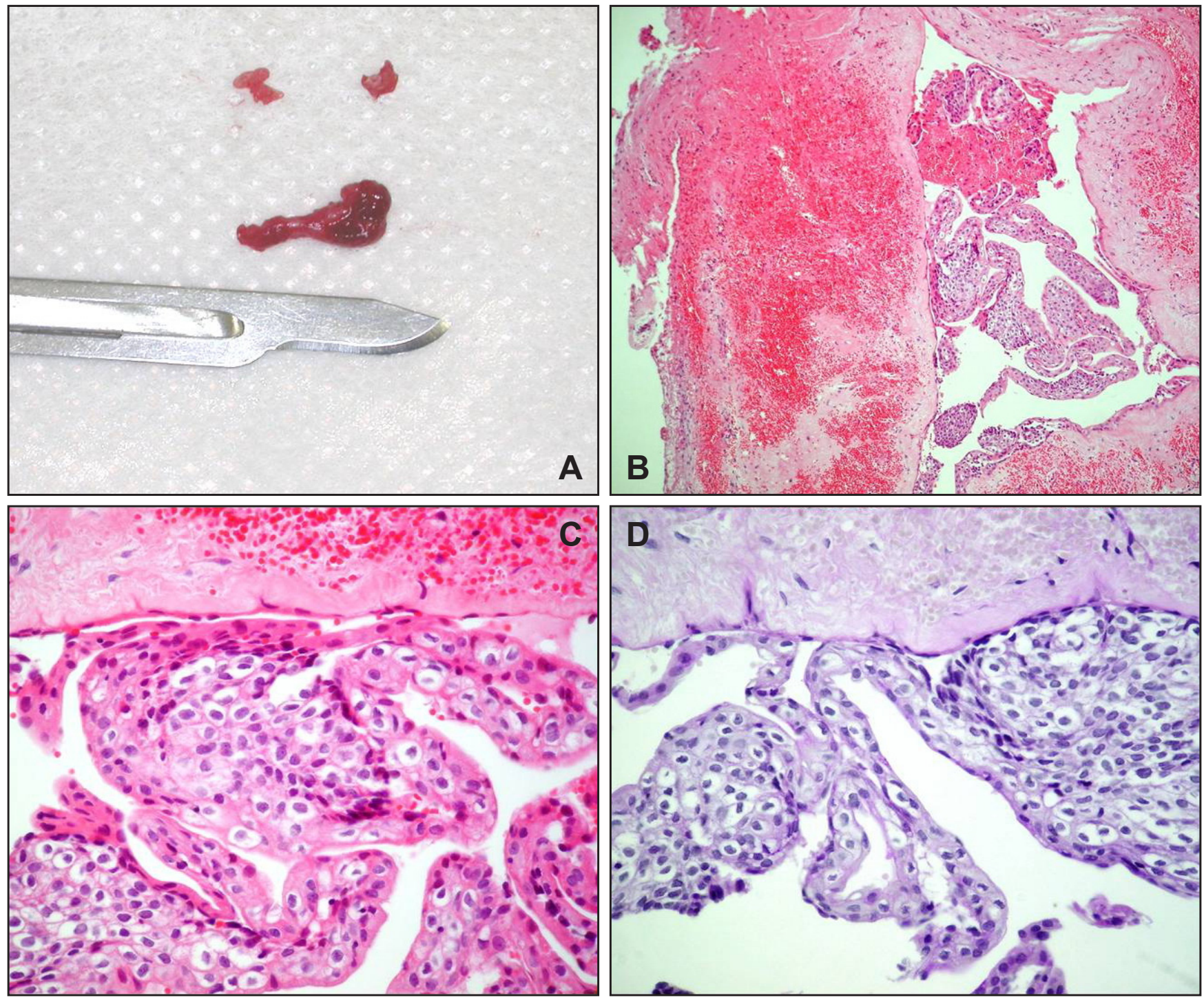

Figure 3. $\mathrm{A}=$ Photograph showing macroscopic aspects of the lesion.

$\mathrm{B}=$ Histopathologic view of the lesion shows one cystic cavity only; the capsule of fibrous tissue showed several bleeding areas and absence of inflammation (hematoxylin and eosin stain, original magnification x25).

$\mathrm{C}=$ Histopathologic view of the lesion shows epithelium lining rich in cells with glycogen (hematoxylin and eosin stain, original magnification $\mathrm{x} 100)$.

$\mathrm{D}=$ Histopathologic view of the lesion shows PAS positive clear cells (PAS x100). 
Table 1. Data from clinicopathological studies of Lateral periodontal cyst (LPC)

\begin{tabular}{|c|c|c|c|c|c|}
\hline Study & $\mathbf{N}$ & Gender & $\begin{array}{l}\text { Mean age } \\
\text { (years) }\end{array}$ & Race & Location \\
\hline Krier 1980 & 1 & Male & 37 & Caucasian & Mandible \\
\hline Cohen et al. 1984 & 24 & $\begin{array}{l}\text { Male: } 12 \\
\text { Female: } 12\end{array}$ & 54 & $\begin{array}{l}\text { Caucasian: } 13 \\
\text { Nigerian: } 11\end{array}$ & $\begin{array}{l}\text { Mandible: } 18 \\
\text { Maxilla: } 6\end{array}$ \\
\hline Rasmusson et al. 1991 & 32 & $\begin{array}{l}\text { Male: } 21 \\
\text { Female: } 11\end{array}$ & 55 & Not reported & $\begin{array}{l}\text { Mandible: } 28 \\
\text { Maxilla: } 4\end{array}$ \\
\hline Buchner et al. 1996 & 1 & Male & 38 & Nigerian & Mandible \\
\hline Carter et al. 1996 & 25 & $\begin{array}{l}\text { Male: } 13 \\
\text { Female: } 12\end{array}$ & 46 & $\begin{array}{l}\text { Caucasian: } 13 \\
\text { Nigerian : } 8 \\
\text { Not reported: } 4\end{array}$ & $\begin{array}{l}\text { Mandible: } 21 \\
\text { Maxilla: } 4\end{array}$ \\
\hline Tolson et al. 1996 & 1 & Male & 50 & Nigerian & Mandible \\
\hline Meltzer JA 1999 & 1 & Female & 73 & Caucasian & Mandible \\
\hline Kerezoudis et al. 2000 & 2 & Male: 2 & 58 & Caucasian & $\begin{array}{l}\text { Mandible: } 1 \\
\text { Maxilla: } 1\end{array}$ \\
\hline Mendes et al. 2006 & 2 & $\begin{array}{l}\text { Male: } 1 \\
\text { Not reported: } 1\end{array}$ & 59 & Not reported & Mandible: 2 \\
\hline Ortega et al. 2007 & 1 & Male & 31 & Not reported & Maxilla \\
\hline Nart et al. 2007 & 1 & Female & 74 & Caucasian & Mandible \\
\hline Formoso Senande et al. 2008 & 11 & $\begin{array}{l}\text { Male: } 6 \\
\text { Female: } 5\end{array}$ & 37 & Not reported & $\begin{array}{l}\text { Mandible: } 3 \\
\text { Maxilla: } 8\end{array}$ \\
\hline Nikitakis et al. 2010 & 2 & $\begin{array}{l}\text { Male: } 1 \\
\text { Female: } 1\end{array}$ & 61 & Caucasian & $\begin{array}{l}\text { Mandible: } 1 \\
\text { Maxilla: } 1\end{array}$ \\
\hline
\end{tabular}

based on the fact that LPC histopathologically presents glycogen-rich clear cells, which is also seen in the dental lamina. The third hypothesis offered that the epithelial remnants of Malassez presented in the roots surface, principal location of the LPC, play a role.

The diagnosis of LPC should be restricted to cysts that are located in the periodontal side. Differentiation between the original lesion and inflammatory cysts and keratocystic odontogenic tumours should be based on clinical, radiographic and pathohistological findings $[\underline{9}, \underline{11}, \underline{21}]$.

Radiographically, the cyst presents as a well circumscribed round or teardrop-shaped radiolucent area (generally not exceeding $1 \mathrm{~cm}$ in diameter) with a radiopaque rim, located laterally to the root of a vital tooth. The periodontal ligament space as a rule is not enlarged and there must not be a communication between the cyst's cavity and the oral environment $[\underline{5}, \underline{11}, 12,19-21]$. Occasionally, LPC may be multicystic, and called as odontogenic botryoid cyst due to macroand microscopic features resemble to "bunch of grapes" (from the Greek word "botrios") $[\underline{11}, \underline{12}, \underline{21}, \underline{22}]$.

The radiographic features may be inconclusive relative to the diagnosis. Other interradicular radiolucencies must be distinguished from the LPC: anatomic radiolucencies, such as the mental foramen, maxillary sinus and the nutrient canals; cyst of pulpal origin, other cysts of the jaws, odontomas and other tumours.
It may resemble a cyst that develops laterally through a side channel accessory in a non vital tooth $[\underline{6}, \underline{12}]$. In a retrospective study of injuries of no endodontic origin, $3.8 \%$ cases of LPC responsible for various treatments without success were found [6].

The histopathology revealed that LPC is a developmental cyst characterized by a thin layer of nonkeratinized epithelium with a thickness of $1-5$ $\mathrm{mm}$, which resemble the reduced enamel epithelium. Nonkeratinized squamous epithelium is composed of 1 - 5 layers of cells displaying a palisade distribution. The epithelium lining can be rich in epithelial plaques composed of the clear fusiform cells rich in glycogen. Some areas of the epithelial thickening, referred to as plaques or theca, are commonly found, and the connective tissue subjacent to the epithelium exhibits a zone of hyalinization. Inflammation is not a feature and the walls of the cyst consist of mature collagen fibrous tissue $[10,12,21]$. However, it is possible to observe the histopathological variant of LPC - botryoid cyst, that should receive a greater attention considering the rate of recurrence $[14, \underline{18}, \underline{23}, 24]$ and unusual presentation $[\underline{25}, \underline{26}]$. The botryoid cyst represents a histopathological variant which presents with multilocular cystic "grapelike" appearance in the bone. Histopathological findings shows multiple cystic spaces lined by nonkeratinized stratified squamous epithelium [14,24-26].

The mobility of mandibular lateral incisor and canine 
reported by the patient can be justified by the cyst growth. However, LPC does not reach proportions that are larger than $1 \mathrm{~cm}[10,12,21]$ while cysts of inflammatory origin tend to grow continuously. In cases of a vital tooth, LPC can still be clinically confused with cysts that develop in inflammatory processes in cases of advanced periodontal disease, where the presence of periodontal inflammation stimulates epithelial proliferation. In most cases the differential diagnosis must be established with radicular cysts, in a view of their high frequency. These lesions are characterized by necrosis of the affected tooth, as a result of which vitality testing proves negative. Follicular or dentigerous cysts are always associated to an impacted tooth (particularly a lower third molar), while primordial cysts are mostly located in the ascending mandibular ramus. Authors suggest the investigation of the possibility of LPC causing isolated bone defects [27].

It is interesting to know that the soft tissue variant of LPC corresponds to gingival cyst of the adult [28]. Some authors state that both lesions have the same histogenesis $[15,28]$. Adult gingival cysts present the same histogenesis, location and clinical features as LPCs, though the rests of odontogenic epithelium appear in the soft tissues - not in bone as in the case of LPCs. As a result, there are no radiological findings [15].

Finally, the importance of diagnosis is especially related to the differential diagnosis with keratocystic odontogenic tumour due to its aggressive and infiltrative growth leading to high recurrence rates which requires a more invasive treatment. The keratocystic odontogenic tumour is one of the most aggressive odontogenic tumours due to its relatively high recurrence rate, relatively fast growth, and the tendency to invade adjacent tissues; it has been reported that it can penetrate even the skull base [29]. Scharfetter et al. [30] demonstrated both: slowly and rapidly proliferating areas in different parts of the keratocystic odontogenic tumour epithelium and the connective tissue wall. $\mathrm{He}$ suggested that the invasive growth of keratocystic odontogenic tumour probably resulted from active growth of the connective tissue wall. Other possible explanations for its high recurrence are increased fibrinolytic activity in the cyst wall, increased mitotic activity, epithelial proliferation in the connective tissue, and a residual dental lamina with subsequent new cyst formation [29]. The bone resorption by the cyst is mediated by activation of osteoclast-like cells [31] and/ or biologically active collagenases [32].

The enucleation is the treatment for LPC, which can often be done without injury to adjacent teeth $[13,17]$. The recurrence is not common; it has been reported with the botryoid variant [ $\underline{33}]$.

\section{CONCLUSIONS}

The lateral periodontal cyst can be considered in the differential diagnosis when a radioloucent lesion appears adjacent to the roots of vital teeth. A histological study is essential in order to confirm the diagnosis. The treatment of choice is surgical removal and subsequent histological evaluation to confirm the diagnosis. Relapses are infrequent.

\section{ACKNOWLEDGMENTS AND DISCLOSURE STATEMENTS}

The authors report no conflicts of interest related to this study. There was no external source of funding for the study.

\section{REFERENCES}

1. Shear M. Developmental odontogenic cysts. An update. J Oral Pathol Med. 1994 Jan;23(1):1-11. Review. [Medline: 8138974] [doi: 10.1111/j.1600-0714.1994.tb00246.x]

2. Shear M. Cysts of the jaws: recent advances. J Oral Pathol. 1985 Jan;14(1):43-59. Review. [Medline: 3918153] [doi: $10.1111 / j .1600-0714.1985 . t b 00465 . x]$

3. Barnes L, Eveson JW, Reichart P, Sidransky D. World Health Organization classification of tumours. Pathology and genetics of head and neck tumours. Lyon: IARC Press; 2005. p. 284.

4. Philipsen HP, Reichart PA. Classification of odontogenic tumours. A historical review. J Oral Pathol Med. 2006 Oct;35(9):525-9. Review. [Medline: 16968232] [doi: 10.1111/j.1600-0714.2006.00470.x]

5. Krier PW. Lateral periodontal cyst. Oral Surg Oral Med Oral Pathol. 1980 May;49(5):475. [Medline: 6929472] [doi: 10.1016/0030-4220(80)90296-0]

6. Ortega A, Fariña V, Gallardo A, Espinoza I, Acosta S. Nonendodontic periapical lesions: a retrospective study in Chile. Int Endod J. 2007 May;40(5):386-90. Epub 2007 Mar 21. Erratum in: Int Endod J. 2007 Aug;40(8):661. [Medline: 17374138] [doi: $\underline{10.1111 / j .1365-2591.2007 .01232 . x]}$ 
7. Kelsey WP 5th, Kalmar JR, Tatakis DN. Gingival cyst of the adult: regenerative therapy of associated root exposure. A case report and literature review. J Periodontol. 2009 Dec;80(12):2073-81. Review. [Medline: 19961391]

8. Nikitakis NG, Brooks JK, Melakopoulos I, Younis RH, Scheper MA, Pitts MA, Al-Mubarak H, Sklavounou A. Lateral periodontal cysts arising in periapical sites: a report of two cases. J Endod. 2010 Oct;36(10):1707-11. Epub 2010 Aug 11. [Medline: 20850683] [doi: 10.1016/i.joen.2010.06.015]

9. Altini M, Shear M. The lateral periodontal cyst: an update. J Oral Pathol Med. 1992 Jul;21(6):245-50. [Medline: 1501155] [doi: 10.1111/j.1600-0714.1992.tb01004.x]

10. Wysocki GP, Brannon RB, Gardner DG, Sapp P. Histogenesis of the lateral periodontal cyst and the gingival cyst of the adult. Oral Surg Oral Med Oral Pathol. 1980 Oct;50(4):327-34. [Medline: 6935584] [doi: 10.1016/0030-4220(80)90417-X]

11. Cohen DA, Neville BW, Damm DD, White DK. The lateral periodontal cyst. A report of 37 cases. J Periodontol. 1984 Apr;55(4):230-4. [Medline: 6585541]

12. Rasmusson LG, Magnusson BC, Borrman H. The lateral periodontal cyst. A histopathological and radiographic study of 32 cases. Br J Oral Maxillofac Surg. 1991 Feb;29(1):54-7. [Medline: 2004079] [doi: 10.1016/0266-4356(91)90177-7]

13. Buchner A, David R, Carpenter W, Leider A. Pigmented lateral periodontal cyst and other pigmented odontogenic lesions. Oral Dis. 1996 Dec;2(4):299-302. Review. [Medline: 9171515] [doi: 10.1111/j.1601-0825.1996.tb00242.x]

14. Carter LC, Carney YL, Perez-Pudlewski D. Lateral periodontal cyst. Multifactorial analysis of a previously unreported series. Oral Surg Oral Med Oral Pathol Oral Radiol Endod. 1996 Feb;81(2):210-6. [Medline: 8665317] [doi: 10.1016/S1079-2104(96)80417-3]

15. Tolson GE, Czuszak CA, Billman MA, Lewis DM. Report of a lateral periodontal cyst and gingival cyst occurring in the same patient. J Periodontol. 1996 May;67(5):541-4. [Medline: $\underline{8724715]}$

16. Meltzer JA. Lateral periodontal cyst: report of a case with 1-year reentry. Int J Periodontics Restorative Dent. 1999 Jun;19(3):299-303. [Medline: 10635176]

17. Kerezoudis NP, Donta-Bakoyianni C, Siskos G. The lateral periodontal cyst: aetiology, clinical significance and diagnosis. Endod Dent Traumatol. 2000 Aug;16(4):144-50. Review. [Medline: 11202873] [doi: $10.1034 /$ j.1600-9657.2000.016004144.x]

18. Mendes RA, van der Waal I. An unusual clinicoradiographic presentation of a lateral periodontal cyst--report of two cases. Med Oral Patol Oral Cir Bucal. 2006 Mar 1;11(2):E185-7. [Medline: 16505801]

19. Nart J, Gagari E, Kahn MA, Griffin TJ. Use of guided tissue regeneration in the treatment of a lateral periodontal cyst with a 7-month reentry. J Periodontol. 2007 Jul;78(7):1360-4. [Medline: 17608593] [doi: 10.1902/jop.2007.060483]

20. Formoso Senande MF, Figueiredo R, Berini Aytés L, Gay Escoda C. Lateral periodontal cysts: a retrospective study of 11 cases. Med Oral Patol Oral Cir Bucal. 2008 May 1;13(5):E313-7. [Medline: 18449116]

21. Eliasson S, Isacsson G, Köndell PA. Lateral periodontal cysts. Clinical, radiographical and histopathological findings. Int J Oral Maxillofac Surg. 1989 Aug;18(4):191-3. [Medline: 2507663] [doi: 10.1016/S0901-5027(89)80048-7]

22. Uçok O, Yaman Z, Günhan O, Uçok C, Doğan N, Baykul T. Botryoid odontogenic cyst: report of a case with extensive epithelial proliferation. Int J Oral Maxillofac Surg. 2005 Sep;34(6):693-5. [Medline: 16053898] [doi: 10.1016/j.ijom.2005.01.005]

23. de Andrade Santos PP, Freitas VS, de Almeida Freitas R, Pinto LP, de Souza LB. Botryoid odontogenic cyst: A clinicopathologic study of 10 cases. Ann Diagn Pathol. 2010 Jun 16. [Epub ahead of print]. [Medline: 20952285] [doi: 10.1016/j.anndiagpath.2010.03.008]

24. Gurol M, Burkes EJ Jr, Jacoway J. Botryoid odontogenic cyst: analysis of 33 cases. J Periodontol. 1995 Dec;66(12):1069-73. [Medline: $\underline{8683420}$ ]

25. Farina VH, Brandão AA, Almeida JD, Cabral LA. Clinical and histologic features of botryoid odontogenic cyst: a case report. J Med Case Reports. 2010 Aug 10;4(1):260. [Medline: 20698969] [doi: 10.1186/1752-1947-4-260] [FREE Full Text]

26. Hethcox JM, Mackey SA, Fowler CB, Kirkpatrick TC, Deas DE. Case report: Diagnosis and treatment of a botryoid odontogenic cyst found in the maxillary anterior region. J Endod. 2010 Apr;36(4):751-4. [Medline: 20307758] [doi: 10.1016/j.joen.2010.01.013]

27. Filipowicz FJ, Page DG. The lateral periodontal cyst and isolated periodontal defects. J Periodontol. 1982 Mar;53(3):145-51. [Medline: 6951028]

28. Giunta JL. Gingival cysts in the adult. J Periodontol. 2002 Jul;73(7):827-31. [Medline: 12146543] [doi: $10.1902 /$ jop.2002.73.7.827]

29. Myoung H, Hong SP, Hong SD, Lee JI, Lim CY, Choung PH, Lee JH, Choi JY, Seo BM, Kim MJ. Odontogenic keratocyst: Review of 256 cases for recurrence and clinicopathologic parameters. Oral Surg Oral Med Oral Pathol Oral Radiol Endod. 2001 Mar;91(3):328-33. [Medline: 11250631] [doi: 10.1067/moe.2001.113109]

30. Scharffetter K, Balz-Herrmann C, Lagrange W, Koberg W, Mittermayer C. Proliferation kinetics-study of the growth of keratocysts. Morpho-functional explanation for recurrences. J Craniomaxillofac Surg. 1989 Jul;17(5):226-33. Review. [Medline: 2668340] [doi: 10.1016/S1010-5182(89)80074-5] 
31. Formigli L, Orlandini SZ, Tonelli P, Giannelli M, Martini M, Brandi ML, Bergamini M, Orlandini GE. Osteolytic processes in human radicular cysts: morphological and biochemical results. J Oral Pathol Med. 1995 May;24(5):216-20. [Medline: 7616461] [doi: 10.1111/j.1600-0714.1995.tb01170.x]

32. Sorsa T, Ylipaavalniemi P, Suomalainen K, Vauhkonen M, Lindy S. Type-specific degradation of interstitial collagens by human keratocyst wall collagenase. Med Sci Res 1988; 16: 1189-1190. [doi: 10.1111/j.1600-0765.1988.tb01618.x]

33. Méndez P, Junquera L, Gallego L, Baladrón J. Botryoid odontogenic cyst: clinical and pathological analysis in relation to recurrence. Med Oral Patol Oral Cir Bucal. 2007 Dec 1;12(8):E594-8. Review. [Medline: 18059246] [doi: 10.1902/jop.2007.060500]

\section{To cite this article:}

de Carvalho LF, Lima CF, Cabral LA, Brandão AA, Almeida JD. Lateral Periodontal Cyst: a Case Report and Literature Review.

J Oral Maxillofac Res 2010;1(4):e5

URL: http://www.ejomr.org/JOMR/archives/2010/4/e5/v1n4e5ht.pdf

doi: $\underline{10.5037 / \text { jomr.2010.1405 }}$

Copyright (C) de Carvalho LF, Lima CF, Cabral LA, Brandão AA, Almeida JD. Accepted for publication in the JOURNAL OF ORAL \& MAXILLOFACIAL RESEARCH (http://www.ejomr.org/), 21 October 2010.

This is an open-access article, first published in the JOURNAL OF ORAL \& MAXILLOFACIAL RESEARCH, distributed under the terms of the Creative Commons Attribution-Noncommercial-No Derivative Works 3.0 Unported License, which permits unrestricted non-commercial use, distribution, and reproduction in any medium, provided the original work and is properly cited. The copyright, license information and link to the original publication on (http://www.ejomr.org/) must be included. 